\title{
РОЗРОБКА СПЕКТРОФОТОМЕТРИЧНОЇ МЕТОДИКИ ВИЗНАЧЕННЯ ФЛАВОНОЇДІВ У КОМПЛЕКСНОМУ ЛІКАРСЬКОМУ ЗАСОБІ НА ОСНОВІ ЕКСТРАКТІВ ЦМИНУ ПІЩАНОГО, НАГІДОК, МОРКВИ ДИКОЇ ТА КУРКУМИ дОвгої
}

\author{
๑о. Г. Смалюх
}

ПАТ «Галичфарм»

\begin{abstract}
Резюме: розроблено спектрофотометричну методику кількісного визначення суми флавоноїдів у лікарському засобі на основі екстрактів цмину піщаного, нагідок, моркви дикої та куркуми довгої в перерахунку на ізосаліпурпузид. Проведено валідацію розробленної методики за такими характеристиками, як лінійність, правильність, прецизійність та робасність.
\end{abstract}

Ключові слова: спектрофотометрія, флавоноїди, комплексний рослинний лікарський засіб.

Вступ. Для дослідження рослинних лікарських засобів (РЛЗ) найбільш придатними є високоселективні хроматографічні методи аналізу, за допомогою яких можливо одночасно провести ідентифікацію та кількісне визначення біологічно активних речовин (БАР) чи маркерів. Однак у ряді випадків для контролю якості багатокомпонентних РЛЗ, де сумарну терапевтичну дію препарату визначає складний комплекс десятків БАР, екстрагованих із рослинної сировини, немає необхідності проводити кількісне визначення кожного окремого компонента хроматографічними методами. Для таких цілей доцільним є використання сумарних методів кількісного визначення (спектрофотометрії чи титриметрії) [1, 2, 5].

Тому метою нашої роботи була розробка методики кількісного визначення флавоноїдів у комплексному лікарському засобі жовчогінної дії, у формі капсул, що містить суміш екстрактів цмину піщаного екстракту сухого (Helichrysum arenarium (L.) Moench), комплексного екстракту густого нагідок квітів (Calendula officinalis $L$ ) та моркви дикої (Daucus carota) (5:1) та куркуми довгої (Curcuma longa) у співвідношенні 0,8: $1: 0,3$.

Методи дослідження. Для досліджень використовували зразки РЛЗ, у формі капсул, виготовлені з екстрактів, для виробництва яких використовували рослинну сировину, зібрану в різних регіонах України (цмину піщаного, нагідок, моркви дикої) або імпортована (куркума довга).

Кількісне визначення флавоноїдів проводили на спектрофотометрі Cary 100 («Varian», Австралія), який пройшов відповідну державну метрологічну атестацію та повірку, а також не- обхідну кваліфікацію відповідно до вимог ДФУ. У роботі використовували спиртові та етилацетатні розчини стандартних зразків ізосаліпурпузиду (ФСЗ ДФУ). Для досліджень використовували реактиви, що відповідали вимогам ДФУ для відповідних методів аналізу, розчини реактивів готували відповідно до вимог ДФу [3].

До складу комплексного РЛЗ входять сухий екстракт цмину піщаного квітів, екстракт моркви дикої плодів та нагідок квітів густий, сухий екстракт куркуми довгої й ефірні олії м'яти перцевої та куркуми. У попередній нашій роботі [4] був запропонований алгоритм стандартизації в ланцюзі: лікарська рослинна сировина - напівпродукт - готовий рослинний лікарський засіб та вибрано основні групи БАР, за якісним та кількісним складом яких буде визначатися якість цього РЛЗ. Якісний склад та кількісний вміст флавоноїдів у РЛЗ визначається флавоноїдами, які екстрагуються з цмину піщаного квітів: ізосаліпурпузид, нарінгенін, апігенін-7глюкозид [10], моркви дикої плодів: лютеолін, апігенін-7-глюкозид, апігенін [7-9, 11] та нагідок квітів: гіперозид, кверцитин, рутин [12, 15]. Зважаючи на те, що компонентний склад флавоноїдів в екстрактах різний, необхідно було встановити, флавоноїди якої групи в обраних умовах пробопідготовки домінують у вилученнях 3 РлЗ. Для цього було проведено дослідження компонентного вмісту флавоноїдів хроматографічними методами (ВЕРХ) готового лікарського засобу. Аналіз проводили на рідинному хроматографі Agilent 1200, хроматографічна колонка XTerra C18, розміром 4,6 х 250 мм 3 розміром часток 5 мкм. Рухома фаза А: розчин натрію дигідрофосфату моногідрату 0,6 г/л, доведений

ISSN 2312-0967. Pharmaceutical review. 2015. № 1 
Аналіз лікарських препаратів

Analysis of drugs

до рН 2,5 кислотою фосфорною; рухома фаза В: ацетонітрил. Швидкість рухомої фази - 1 мл/хв, градієнтне елюювання. Детектування проводили за допомогою діодно-матричного детектора при довжині хвилі 330 нм. Об'єм проби, що вводився - 100 мкл, температура колонки - $25{ }^{\circ} \mathrm{C}$, час хроматографування 60 хв. Ідентифікацію речовин проводили шляхом порівняння часів утримування піків на хроматограмі випробовуваного розчину з часами утримування стандартних речовин. Результати досліджень представлено у таблиці 1 та на рисунку 1.

Згідно з проведеними і представленими у таблиці 1 розрахунками, ізосаліпурпузид складає близько 40 \% від вмісту суми флавоноїдів у РЛЗ, тому дана речовина була вибрана як стандарт для перерахунку кількісного вмісту флавоноїдів. Зважаючи на те, що в екстрактах містяться флавоноїди як у формі глікозидів, так і у формі агліконів, ми апробували методику кількісного визначення флавоноїдів після гідролізу, описану в монографії ДФу Нагідок квіти [12]. Суму флавоноїдів визначали методом диференційної спектрофотометрії за реакцією утворення фотометрованої сполуки із алюмінію хлоридом. Як компенсаційний розчин використовували вихідний розчин без додавання алюміній хлориду.

\section{Методика № 1}

Вихідний розчин 1. 300 мг (точна наважка) порошку розтертої капсульної маси поміщали у центрифужну пробірку, додавали 20 мл води $P$,
Таблиця 1. Результати ідентифікації і визначення флавоноїдів у зразках капсул методом високоефективної рідинної хроматографії

\begin{tabular}{|l|c|}
\hline \multicolumn{1}{|c|}{ Речовина } & $\begin{array}{c}\text { Відносний вміст, \% } \\
\text { метод внутрішньої } \\
\text { нормалізації }\end{array}$ \\
\hline Гіперозид & 1,6 \\
\hline "Неідентифікований пік & 9,3 \\
\hline Апігенін-7-глюкозид & 13,7 \\
\hline Ізосаліпурпузид & 41,4 \\
\hline Лютеолін & 8,4 \\
\hline Нарингінін & 5,1 \\
\hline Апігенін & 20,5 \\
\hline
\end{tabular}

Примітка. *-УФ-спектр речовини, яка позначена як неідентифікований пік, за ходом кривої світлопоглинання і положенням максимуму в ділянці поглинання флавоноїдів дозволяє припустити належність цієї речовини до флавоноїдів, тому площу піку цієї речовини враховували при розрахунку вмісту окремих представників методом внутрішньої нормалізації.

інтенсивно струшували протягом 5 хв, центрифугували 5 хв зі швидкістю 5000 об/хв; надосадову рідину фільтрували через фільтр «біла стрічка» у мірну колбу місткістю 100 мл. Вилучення водою повторювали ще 3 рази за тих же умов. Фільтр промивали 10 мл води $P$ і доводили об'єм розчину водою $Р$ до 100,0 мл.

Випробовуваний розчин. До 2,0 мл вихідного розчину 1 додавали 2,0 мл розчину 50 г/л алю-

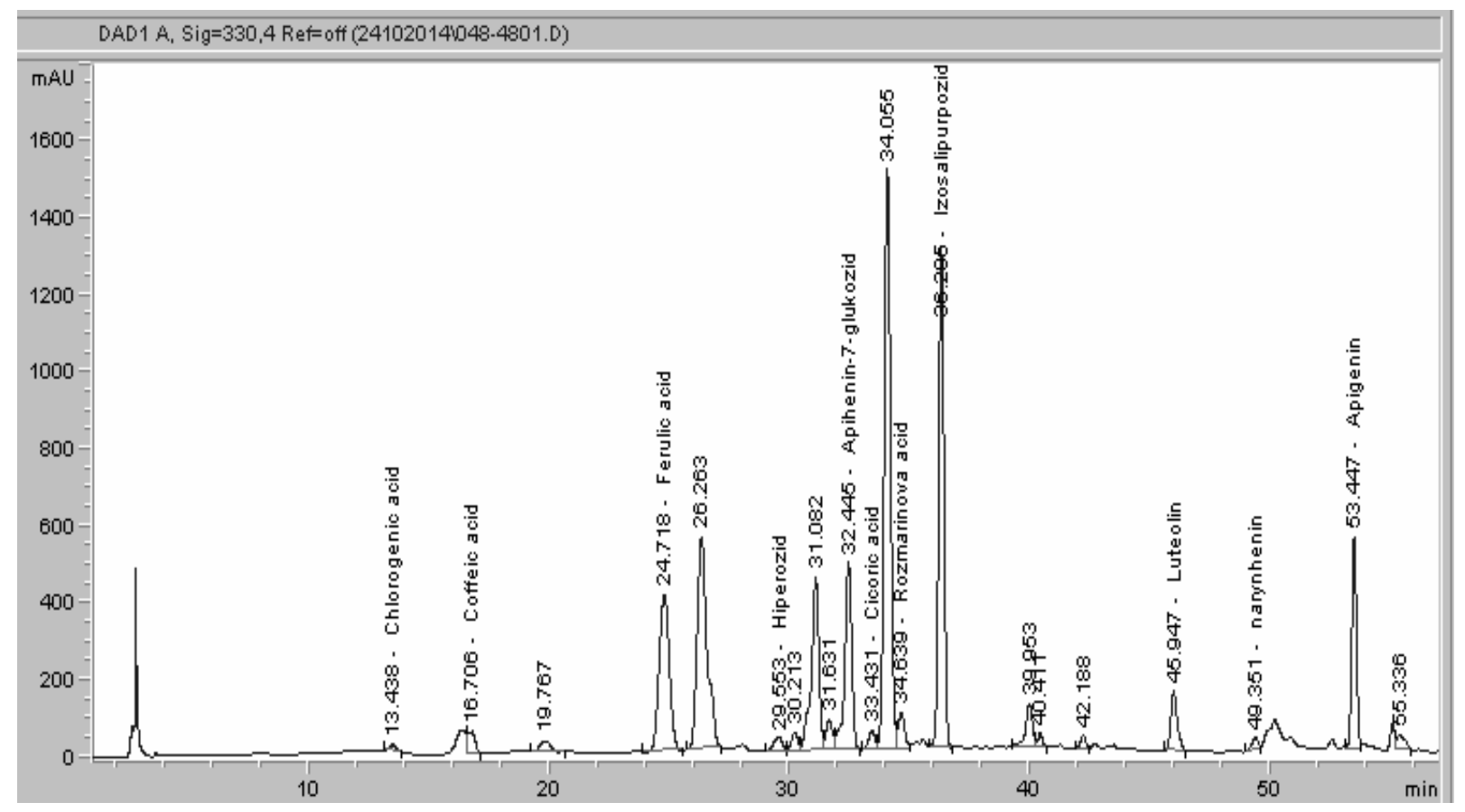

Рис. 1. Типова хроматограма, отримана при ідентифікації флавоноїдів у зразках капсул методом високоефективної рідинної хроматографії.

ISSN 2312-0967. Фармацевтичний часопис. 2015. № 1 
мінію хлориду $P$ в етанолі $P$, нагрівали у водяній бані при температурі $(70 \pm 5){ }^{\circ} \mathrm{C}$ протягом 5 хв, охолоджували до кімнатної температури і доводили об'єм розчину етанолом $P$ до 25,0 мл.

Компенсаційний розчин 1. 2,0 мл вихідного розчину 1, нагрівали у водяній бані при температурі $(70 \pm 5)^{\circ} \mathrm{C}$ протягом 5 хв, охолоджували до кімнатної температури і доводили об'єм розчину етанолом Р до 25,0 мл.

Вихідний розчин 2. 10 мг ФСЗ ізосаліпурпозиду, висушеного до постійної маси при температурі $100-105{ }^{\circ} \mathrm{C}$, розчиняли в 50 мл етанолу $P$, доводили об'єм розчину тим самим розчинником до 100,0 мл.

Розчин порівняння. До 2,0 мл вихідного розчину 2 додавали 2,0 мл розчину 50 г/л алюмінію хлориду $P$ в етанолі $P$, нагрівали у водяній бані при температурі $(70 \pm 5){ }^{\circ} \mathrm{C}$ протягом 5 хв, охолоджували до кімнатної температури і доводили об'єм розчину етанолом $P$ до 25,0 мл.

Компенсаційний розчин 2. 2,0 мл вихідного розчину 2, нагрівали у водяній бані при температурі $(70 \pm 5)^{\circ} \mathrm{C}$ протягом 5 хв, охолоджували до кімнатної температури і доводили об'єм розчину етанолом $P$ до 25,0 мл.

Оптичну густину (ДФУ, 2.2.25) випробовуваного розчину вимірювали в максимумі спектра при довжині хвилі (420 \pm 5$)$ нм відносно компенсаційного розчину 1. Паралельно вимірювали оптичну густину розчину порівняння, відносно компенсаційного розчину 2.

Вміст суми флавоноїдів (X) (у мг), у перерахунку на ізосаліпурпозид, розраховували за формулою:

$$
X=\frac{A \cdot m_{0} \cdot b}{A_{0} \cdot m},
$$

де $A$ - оптична густина випробовуваного розчину;

$A_{0}$ - оптична густина розчину порівняння;

$m$ - маса наважки, у міліграмах;

$m_{0}$ - маса наважки ФСЗ ізосаліпурпозиду, у міліграмах;

b - середня маса вмісту однієї капсули, у міліграмах.

\section{Методика № 2}

Вихідний розчин. 500 мг (точна наважка) порошку розтертої капсульної маси поміщали у центрифужну пробірку, додавали 8,0 мл розчину хлористоводневої кислоти Р1 і 15 мл води Р. Пробірку поміщали в ультразвукову баню на 10 хв, після чого центрифугували 5 хв при 5000 об/хв, надосадову рідину фільтрували через фільтр «біла стрічка» в конічну колбу з шліфом місткістю 100 мл. Фільтр промивали тричі по 5,0 мл розчи- ну хлористоводневої кислоти P1 і 20 мл води Р при вищевказаних умовах. До отриманого розчину додавали 1,0 мл розчину гексаметилентетраміну $P$ (5 г/л) і 30 мл ацетону $P$, кип'ятили із зворотним холодильником протягом 30 хв, охолоджували і кількісно переносили рідину в мірну колбу місткістю 200 мл, колбу промивали ацетоном $P$ і доводили цим же розчинником до позначки. 25,0 мл отриманого розчину поміщали в ділильну лійку місткістю 100 мл, додавали 20 мл води $P$ і 15 мл етилацетату $P$, струшували протягом 5 хв. Після поділу шарів нижній (водний) шар зливали у склянку місткістю 100 мл, а верхній (органічний) - у конічну колбу місткістю 100 мл, яку закривали корком. Водну фракцію знову поміщали в ділильну лійку і повторювали екстракцію ще три рази порціями по 15 мл, 15 мл і 10 мл етилацетату $P$, струшуючи щоразу 5 хв. Об'єднані етилацетатні вилучення кількісно, за допомогою 25 мл води $P$, переносили в ділильну лійку і струшували 2 рази з водою $P$, по 25 мл і 50 мл відповідно, протягом 5 хв. Етилацетатне вилучення фільтрували через фільтр «біла стрічка» 310 г натрію сульфату безводного $P$ у мірну колбу місткістю 50 мл (фільтр з натрію сульфатом безводним $P$ попередньо змочували етилацетатом Р). Ділильну лійку і фільтр промивали 5 мл етилацетату $P$ і доводили вміст в мірній колбі до 50,0 мл етилацетатом $P$.

Випробовуваний розчин. До 10,0 мл вихідного розчину додавали 1,0 мл реактиву алюмінію хлориду $P$, доводили об'єм розчину 5\% (об/об) розчином оцтової кислоти льодяної Р в метанолі $P$ до 25,0 мл.

Компенсаційний розчин 1. 10,0 мл вихідного розчину доводили 5\% (об/об) розчином оцтової кислоти льодяної Р в метанолі Р до 25,0 мл.

Вихідний розчин 2. 20 мг ФСЗ ізосаліпурпозиду, висушеного до постійної маси при температурі $100-105{ }^{\circ} \mathrm{C}$, розчиняли в 30 мл етилацетату $P$ на ультразвуковій бані протягом 10 хв, доводили об'єм розчину тим самим розчинником до 50,0 мл. 5,0 мл одержаного розчину доводили етилацетатом $P$ до 50,0 мл.

Розчин порівняння. До 10,0 мл вихідного розчину 2 додавали 1,0 мл реактиву алюмінію хлориду $P$, доводили об'єм розчину 5\% (об/об) розчином оцтової кислоти льодяної $P$ в метанолі $P$ до 25,0 мл.

Компенсаційний розчин 2. 10,0 мл вихідного розчину 2 доводили 5\% (об/об) розчином оцтової кислоти льодяної Р в метанолі $Р$ до 25,0 мл.

Через 30 хв після приготування записували спектр випробовуваного розчину в діапазоні від 350 нм до 500 нм і вимірювали оптичну густину в максимумі спектра при довжині хвилі (420 \pm 5$)$ нм в кюветі з товщиною шару 10 мм відносно компенсаційного розчину. За тих же самих умов про-

ISSN 2312-0967. Pharmaceutical review. 2015. № 1 
водили вимірювання оптичної густини розчину порівняння відносно компенсаційного розчину 2.

Вміст суми флавоноїдів (X) (в мг), в перерахунку на ізосаліпурпузид, розраховували за формулою:

$$
X=\frac{A \cdot m_{0} \cdot 10 \cdot b}{A_{0} \cdot m}
$$

де $A$ - оптична густина випробовуваного розчину в максимумі спектра при довжині хвилі (420 \pm 5) $\mathrm{HM}$;

$A_{0}$ - оптична густина розчину порівняння в максимумі спектра при довжині хвилі (420 \pm 5$)$ нм;

$m$ - маса наважки досліджуваного зразка, в міліграмах;

$m_{0}$ - маса наважки ФСЗ ізосаліпурпозиду, у міліграмах;

b - середня маса вмісту однієї капсули, в міліграмах.

Результати й обговорення. Як видно з рисунка 2, в умовах кількісного визначення флавоноїдів згідно 3 методикою № 1, диференціальний електронний спектр випробовуваного розчину має чітко виражений максимум при довжині хвилі $(427 \pm 2)$ нм і плече в ділянці 470 нм. Це

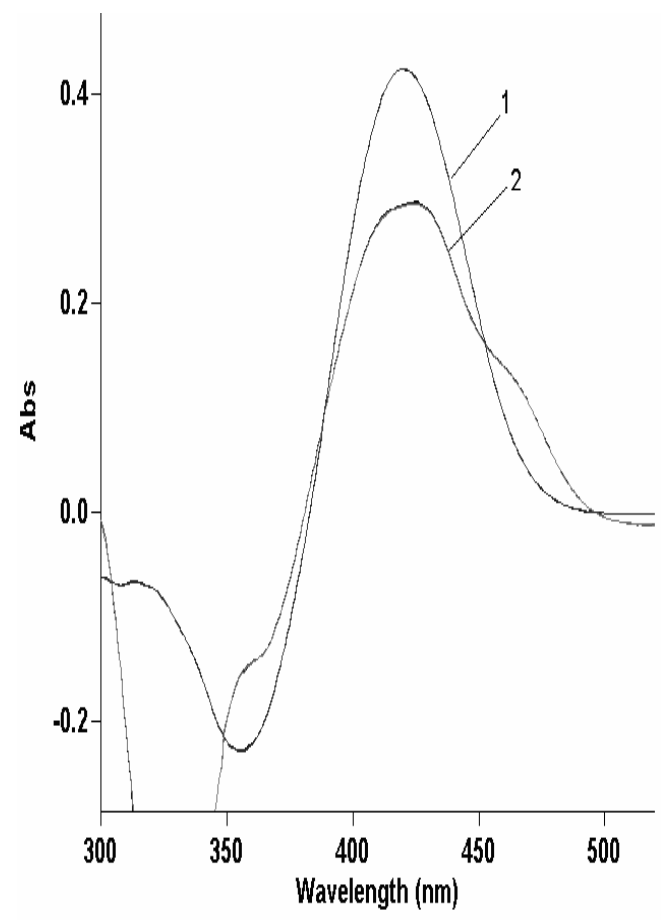

Рис. 2. Диференціальний електронний спектр поглинання розчину ізосаліпурпузиду (1) та випробовуваного розчину (2) в умовах кількісного визначення згідно з методикою № 1. зумовлено тим, що у РЛЗ присутні різні сполуки флавоноїдів, комплекси яких з алюміній хлоридом мають максимуми поглинання, що різняться за довжиною хвилі. Це може спричиняти похибку результатів визначення, оскільки виникає дилема щодо вибору довжини хвилі максимуму поглинання - вона завжди буде «дрейфувати» внаслідок того, що для різних серій екстрактів може спостерігатись коливання вмісту окремих флавоноїдів та їх співвідношення.

У Державній фармакопеї України (ДФУ) для деяких видів рослинної сировини наведено методики кількісного визначення флавоноїдів, що ґрунтуються на попередньому гідролізі глікозидів флавоноїдів до відповідних агліконів, екстракції агліконів етилацетатом і наступному їх комплексоутворенні з алюмінію хлоридом [12]. Такий підхід нами було використано при розробці методики кількісного визначення флавоноїдів у сировині моркви дикої плодах та комплексному густому екстракті моркви дикої плодів та нагідок квітів.

Приклади спектрів поглинання в умовах кількісного визначення флавоноїдів згідно 3 методикою № 2 наведено на рисунку 3.

Як видно з рисунка 2, максимум поглинання для випробовуваного розчину знаходився в діапазоні 417 - 422 нм. Такий діапазон максимумів поглинання свідчить про різноманітність окре-

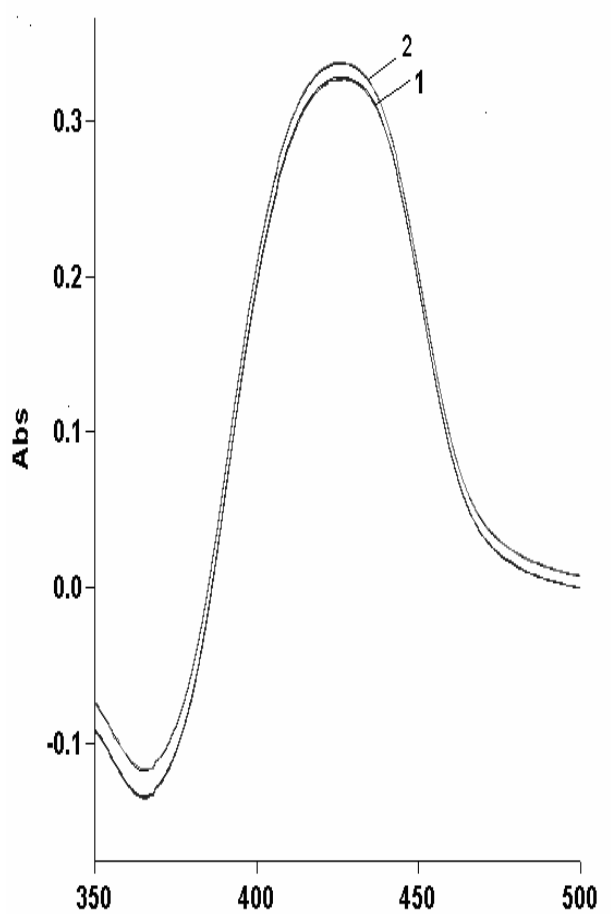

Рис. 3. Диференціальний електронний спектр поглинання розчину ізосаліпурпузиду (1) та випробовуваного розчину (2) в умовах кількісного визначення згідно з методикою № 2.

ISSN 2312-0967. Фармацевтичний часопис. 2015. № 1 
мих сполук флавоноїдів і різне їх співвідношення. Комплексні сполуки флавоноїдів 3 алюмінію хлоридом, відповідно до електронної будови їх молекул, дещо відрізняються довжиною хвилі положення максимуму поглинання і, відповідно, мають дещо різні питомі показники поглинання для окремих представників, тому коливання співвідношення флавоноїдів у різних зразках РЛЗ приводить до «дрейфу» довжини хвилі положення максимуму поглинання. Однак завдяки проведеному гідролізу глікозидів флавоноїдів та наступній екстракції агліконів етилацетатом вдалося отримати більш однорідні значення максимумів поглинання (рис. 3).

При виборі аналітичного маркера для перерахунку суми флавоноїдів основним критерієм був збіг максимумів поглинання випробовуваних розчинів і розчинів порівняння та присутність даного компонента у досліджуваному зразку. Порівнюючи хід кривої світлопоглинання та положення максимуму випробовуваного розчину з виглядом і положенням максимуму поглинання розчину порівняння, встановлено, що в умовах кількісного визначення, згідно з методикою 2, максимум поглинання випробовуваного розчину та розчину порівняння ізосаліпурпузиду збігаються (рис. 3). Саме тому кількісний вміст суми флавоноїдів, визначений згідно з методикою №2, розраховували у перерахунку на ізосаліпурпузид.

Таким чином, для визначення вмісту флавоноїдів у РЛЗ обрано методику № 2. Для підтвердження придатності обраної методики для контролю якості РлЗ проведено її валідацію.

Вибір та розрахунок валідаційних характеристик проводили згідно з вимогами ДФу [13]. Розрахунок валідаційних характеристик був проведений, виходячи з повної невизначеності аналізу $\left(\Delta_{\mathrm{AS}}\right) \leq 5 \%$. Для запропонованої методики ми досліджували такі валідаційні характеристики: лінійність, правильність і прецизійність, робасність $[6,13,14]$. Зважаючи на те, що про- бопідготовка включає декілька стадій вилучення/вимивання флавоноїдів з капсульної маси, триразове екстрагування етилацетатом після гідролізу тощо, в ході валідації необхідно було довести, що вибрана кількість повторів операцій достатня для повного вилучення, а вибрані кількості доданих реагентів - достатні для забезпечення повноти перебігу реакції.

При вивченні лінійності досліджували діапазон 20 - 200 \% від середнього вмісту флавоноїдів у капсулі (6,5 мг), відібрані аліквоти розчинів зважували на аналітичних вагах для точнішого переведення у нормалізовані координати (табл. 2). Усі аналітичні операції проводили відповідно до умов, описаних у методиці № 2. Спектри випробовуваних розчинів, отриманих при вивченні лінійності, правильності і прецизійності представлено на рисунку 4. Проведення розрахунків та висунення критеріальних вимог здійснювали відповідно до [6, 13, 14]. Критерії лінійності і параметри лінійної залежності, а також результати визначення прецизійності і правильності представлені у таблицях 3, 4.

Виходячи із отриманих значень та виконання вимог до лінійності, правильності та прецизійності, можна стверджувати про прийнятність методики за цими характеристиками в заданому діапазоні вимірювань.

Для доказу ефективності вилучення флавоноїдів з капсульної маси та ефективності екстрагування агліконів етилацетатом після гідролізу, проводили ще одну додаткову операцію вилучення та екстракції. Відповідне вилучення і екстракт були оброблені в умовах кількісного визначення, аналогічно випробовуваному розчину та були проаналізовані спектри цих розчинів з алюміній хлоридом. Максимумів поглинання в ділянці

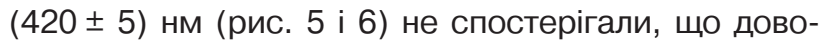
дить достатність запропонованої у методиці кратності вилучення з капсульної маси флавоноїдів та кратності екстракцій агліконів після гідролізу.

При вивченні робасності методики було досліджено вплив кількостей реагентів гексамети-

Таблиця 2. Вихідні дані для дослідження валідаційних характеристик методики кількісного визначення суми флавоноїдів

\begin{tabular}{|c|c|c|c|c|}
\hline Теор. вміст, \% & $\mathrm{A}$ & $\mathrm{C}_{\mathrm{i} \mathrm{введено}, \%} \%$ & $\mathrm{C}_{\mathrm{i} \text { знайдено }}, \%$ & $\mathrm{C}_{\mathrm{i} \text { знайдено }} \cdot 100 / \mathrm{C}_{\mathrm{i}_{\text {введено }}} \%$ \\
\hline 20 & 0.072 & 20.1 & 19.7 & 99.3 \\
\hline 40 & 0.144 & 39.9 & 40.0 & 100.2 \\
\hline 60 & 0.219 & 59.8 & 60.8 & 101.7 \\
\hline 80 & 0.289 & 80.0 & 80.2 & 100.3 \\
\hline 100 & 0,361 & 100.0 & 100.0 & 100.0 \\
\hline 120 & 0.430 & 119.6 & 119.3 & 99.8 \\
\hline 140 & 0.500 & 139.6 & 138.7 & 99.3 \\
\hline 160 & 0.570 & 160.1 & 158.0 & 98.7 \\
\hline 180 & 0.641 & 179.5 & 177.7 & 99.0 \\
\hline 200 & 0.719 & 199.2 & 199.4 & 100.1 \\
\hline
\end{tabular}

ISSN 2312-0967. Pharmaceutical review. 2015. № 1 
Аналіз лікарських препаратів

Analysis of drugs

Таблиця 3. Результати дослідження лінійності методики кількісного визначення суми флавоноїдів

\begin{tabular}{|l|c|c|c|}
\hline \multicolumn{1}{|c|}{ Параметр лінійності } & Значення параметра & Критерій & Висновок \\
\hline $\mathrm{b}$ & 0.9910 & & \\
\hline $\mathrm{S}_{\mathrm{b}}$ & 0.004557 & & \\
\hline $\mathrm{a}$ & $|0.6158|$ & $\begin{array}{c}\leq|1.0491926| \\
\leq|1.934307|\end{array}$ & Витримується за першим критерієм \\
\hline $\mathrm{S}_{\mathrm{a}}$ & 0.5642 & & \\
\hline $\mathrm{RSD}_{0}$ & 0.8250 & & Витримується \\
\hline $\mathrm{RSD}_{0} / \mathrm{b}$ & $|0.8324|$ & $5.9888949 \mid$ & Витримується \\
\hline $\mathrm{RSD}_{\mathrm{y}}$ & 54.97 & & \\
\hline $\mathrm{r}$ & $\mid 0.99989$ & $>0.99880286$ & \\
\hline
\end{tabular}

Таблиця 4. Результати дослідження прецизійності та правильності методики кількісного визначення суми флавоноїдів

\begin{tabular}{|l|l|l|l|l|l|}
\hline \multicolumn{2}{|c|}{ Параметр } & \multicolumn{1}{|c|}{ Значення } & \multicolumn{1}{|c|}{ Критерій 1} & \multicolumn{1}{|c|}{ Критерій 2} & Висновок \\
\hline Прецизійність & $\Delta \mathrm{d}$ & 1.537 & $\leq 5$ & & Витримується \\
\hline Правильність & $\left|\mathrm{d}_{\mathrm{cp}}-100\right|$ & $|-0.1670|$ & $\leq 0.486$ & $\leq 1.58$ & $\begin{array}{l}\text { Витримується за } \\
\text { першим критерієм }\end{array}$ \\
\hline $\begin{array}{l}\mathrm{S}_{\mathrm{d}, \mathrm{r}}(\%)=0.8387 \\
\alpha(95,1,9)=1.833\end{array}$ & & & & \\
\hline
\end{tabular}

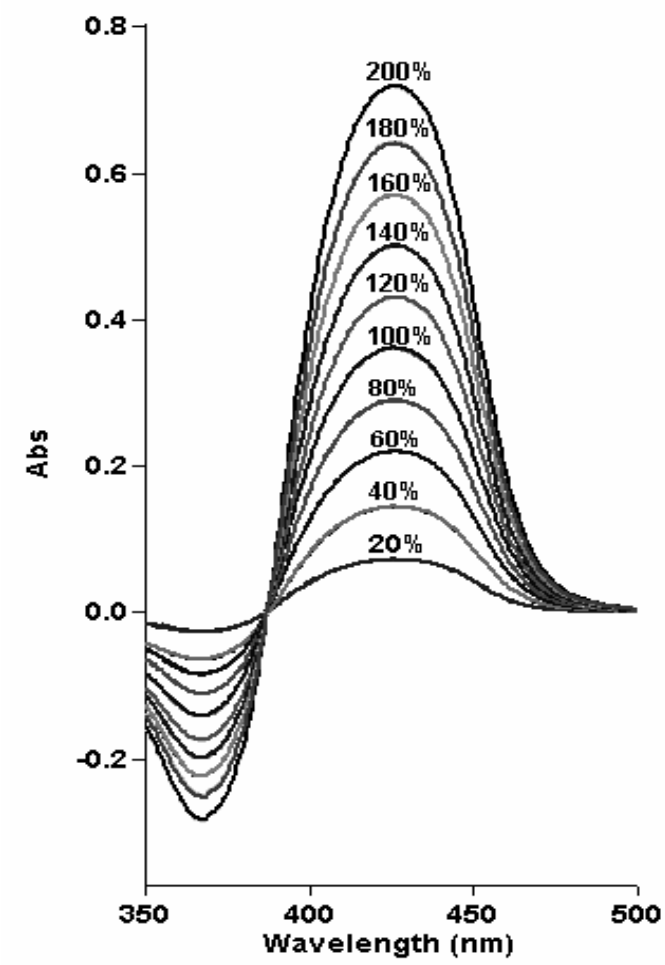

Рис. 4. Диференціальні електронні спектри поглинання модельних випробовуваних розчинів в умовах кількісного визначення згідно з методикою

№ 2, отриманих при вивченні лінійності, правильності та прецизійності.

лентетраміну, алюмінію хлориду та тривалості операцій кип'ятіння й утворення фотометрованої сполуки флавоноїдів з алюмінію хлоридом.

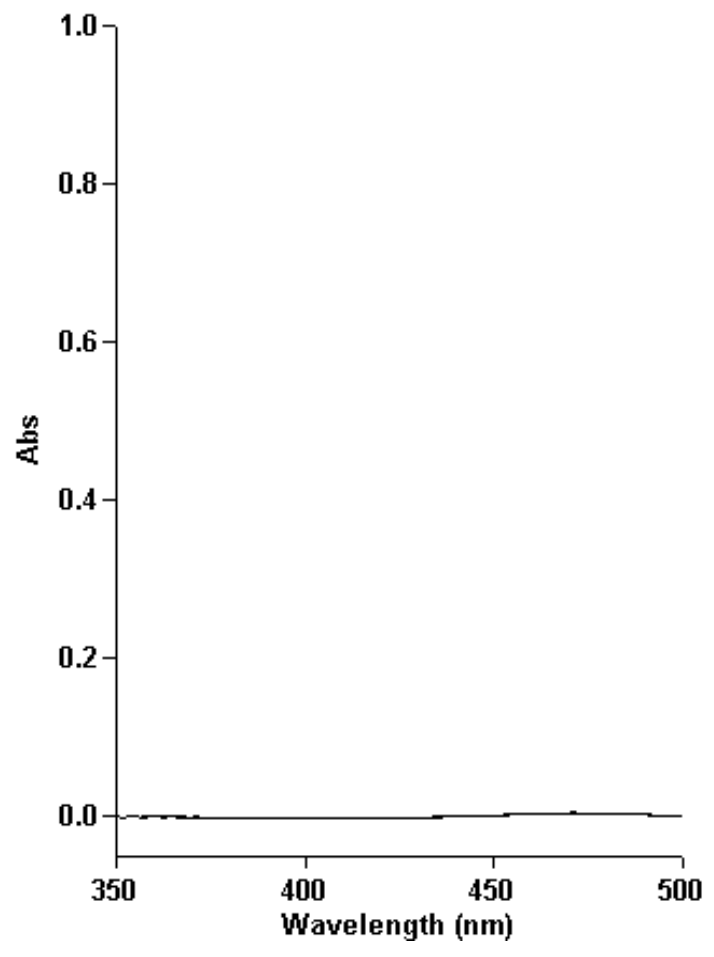

Рис. 5. Диференціальний електронний спектр поглинання випробовуваного розчину в умовах кількісного визначення згідно з методикою № 2, отриманого при вивченні ефективності пробопідготовки (повнота вилучення з капсульної маси).

Результати випробувань відповідають вимогам валідаційних характеристик. Спектри представлено на рисунках $7-11$.

ISSN 2312-0967. Фармацевтичний часопис. 2015. № 1 


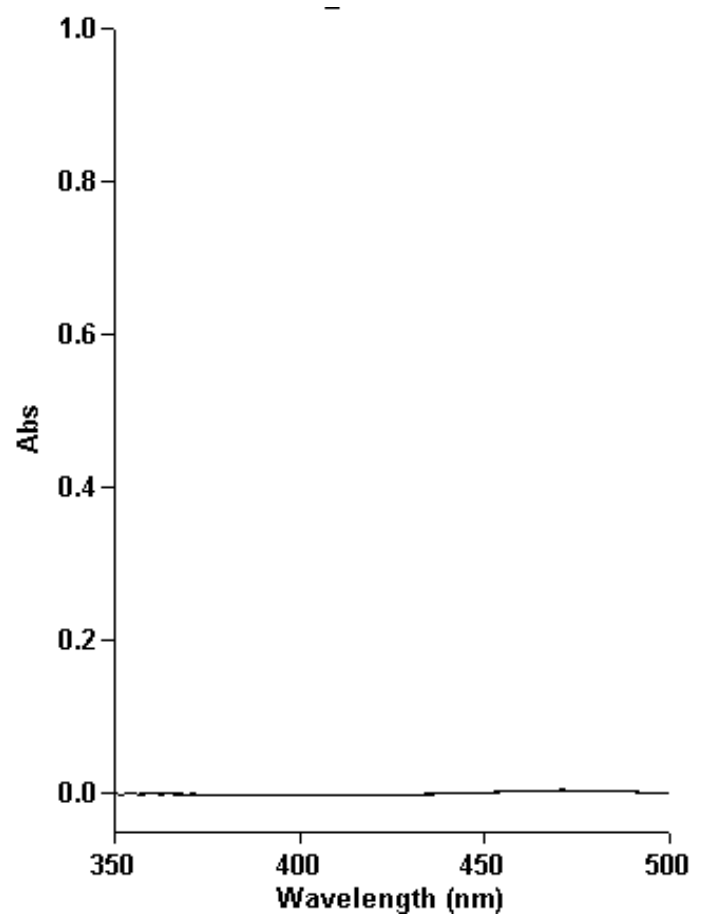

Рис. 6. Диференціальний електронний спектр поглинання випробовуваного розчину в умовах кількісного визначення згідно з методикою № 2,

отриманого при вивченні ефективності пробопідготовки (повнота екстракції етилацетатом).

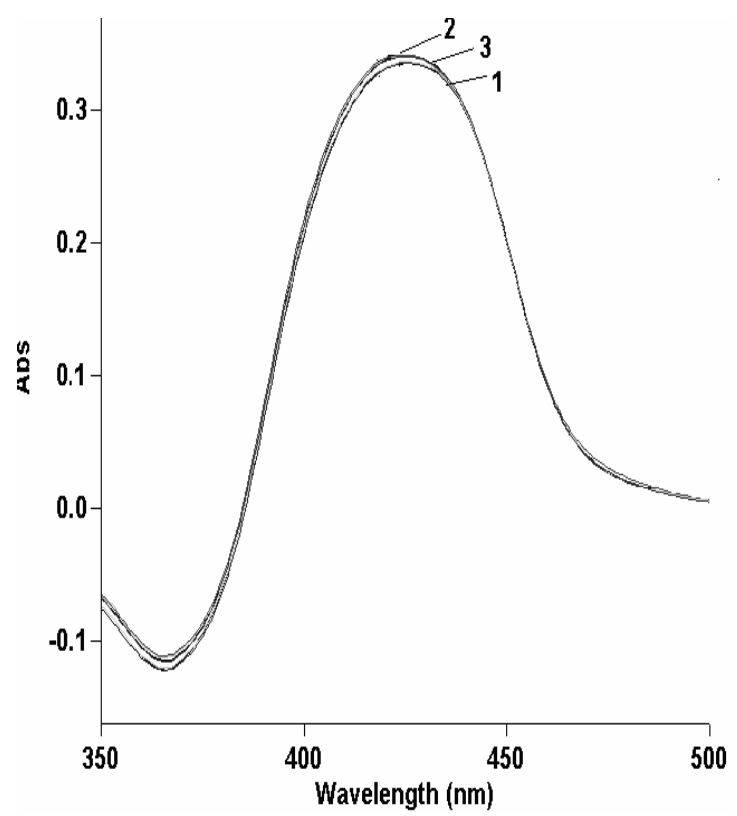

Рис. 8. Диференціальні електронні спектри поглинання випробовуваних розчинів з використанням 0,8 мл (1) 1,0 мл (2) та 1,2 (3) мл розчину алюмінію хлориду в умовах кількісного визначення згідно з методикою № 2, отриманих при вивченні робасності.

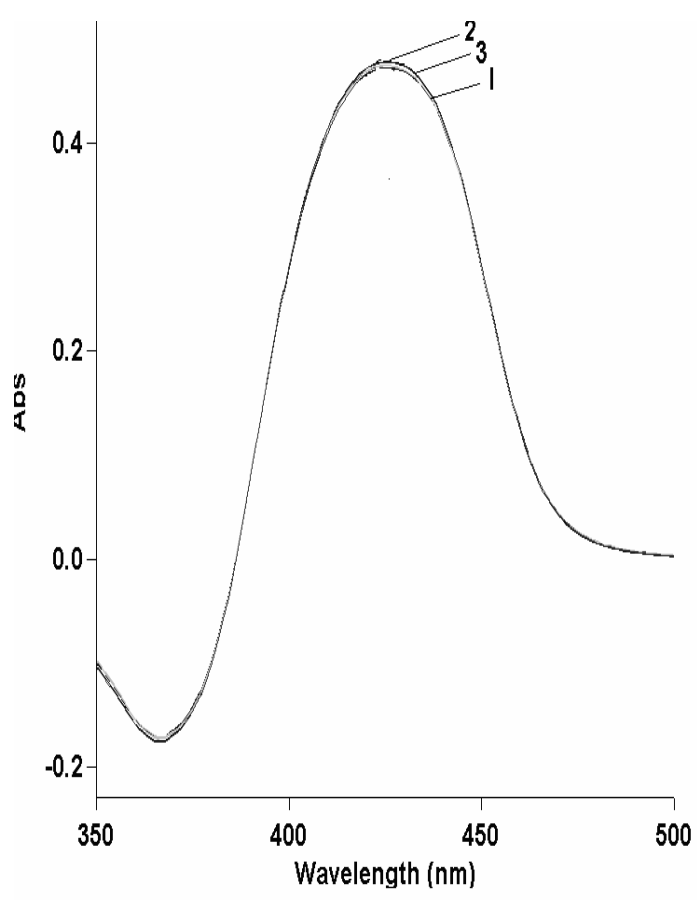

Рис. 7. Диференціальні електронні спектри поглинання випробовуваних розчинів 3 використанням 0,8 мл (1) 1,0 мл (2) та 1,2 (3) мл гексаметилентетраміну 5 г/л в умовах кількісного визначення згідно з методикою №2, отриманих при вивченні робасності.

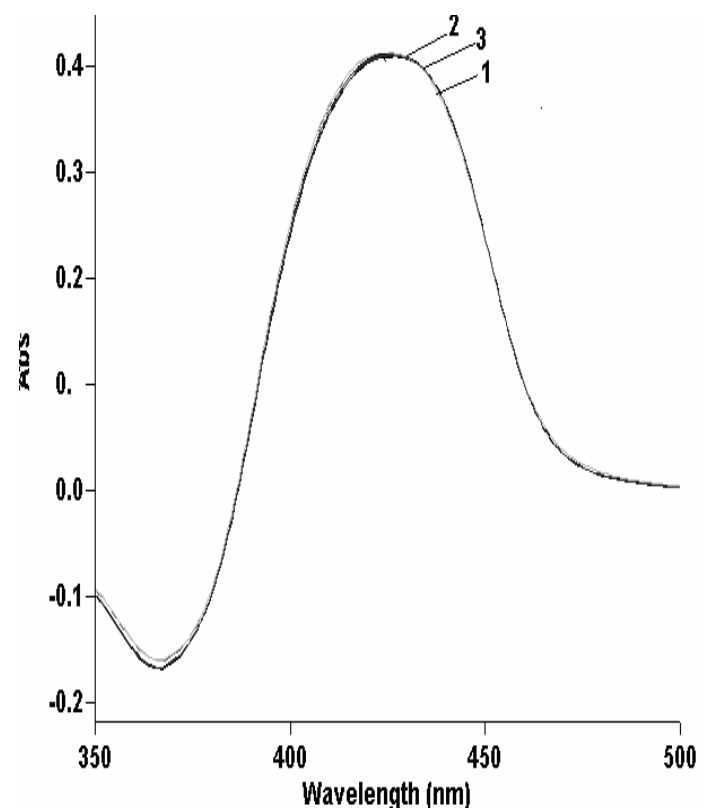

Рис. 9. Диференціальні електронні спектри поглинання випробовуваних розчинів 3 використанням 4,5 \% (об/об) (1) 5,0 \% (об/об) (2) та 5,5 \% (об/об) (3) кислоти оцтової в метанолі в умовах кількісного визначення згідно з методикою

№ 2, отриманих при вивченні робасності.

ISSN 2312-0967. Pharmaceutical review. 2015. № 1 
Аналіз лікарських препаратів

Analysis of drugs

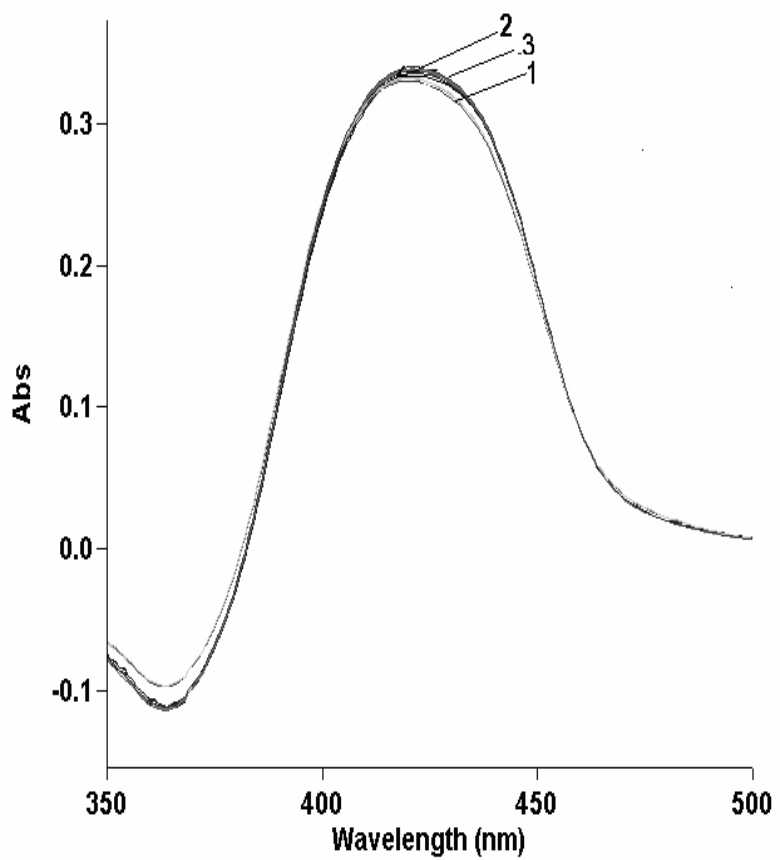

Рис. 10. Диференціальні електронні спектри поглинання випробовуваних розчинів, отриманих

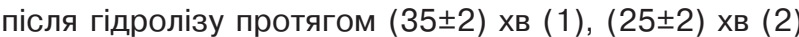

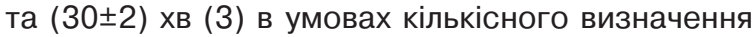
згідно з методикою № 2 (вплив тривалості гідролізу).

Висновки. 1. Розроблена спектрофотометрична методика кількісного визначення флавоноїдів у багатокомпонентному РЛЗ, яка базується на вимірюванні поглинання комплексних сполук агліконів флавоноїдів з алюмінію хлоридом, обґрунтовано вибір ізосаліпурпузиду як аналі-

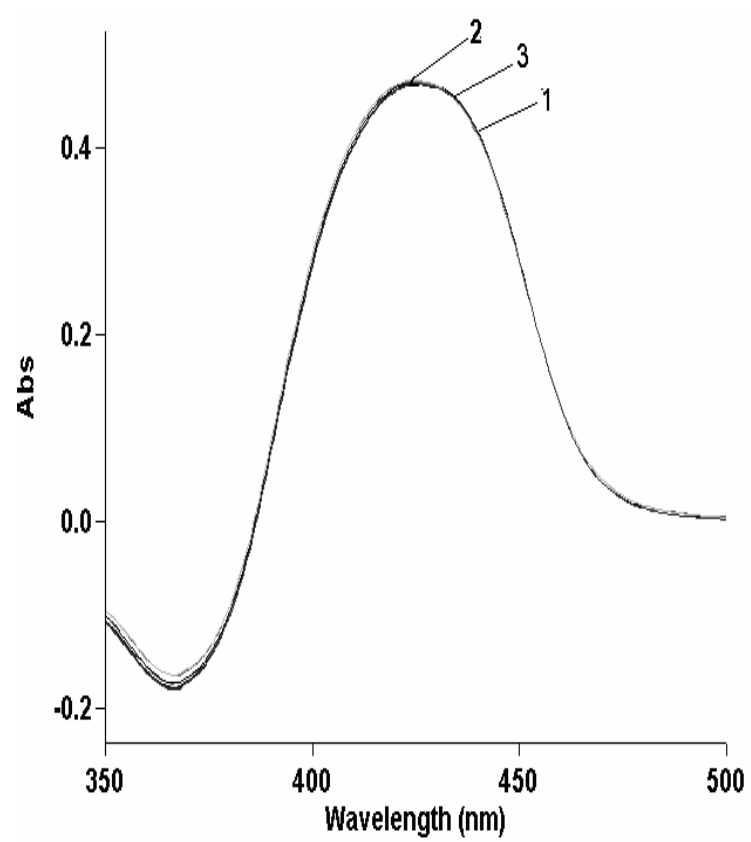

Рис. 11. Диференціальні електронні спектри поглинання випробовуваних розчинів, отриманих через $(25 \pm 2)$ хв (1), $(30 \pm 2)$ хв (2) та $(60 \pm 2)$ хв (3) в умовах кількісного визначення згідно з методикою № 2, (стійкість розчину в часі).

тичного маркера та досліджено оптимальні умови пробопідготовки.

2. У ході валідації розробленої методики досліджено і підтверджено її прийнятність за такими характеристиками, як лінійність, правильність і прецизійність та робасність.

\section{Література}

1. Сур С. В. Методологія оцінки якості рослинних лікарських засобів на підставі результатів, одержаних за допомогою сучасних аналітичних методів // Фармацевтичний журнал. - 2002. - № 6. - С. 64-71.

2. Гризодуб А. И. Особенности фармакопейных подходов к количественному определению лекарственного растительного сырья и суммарных фитопрепаратов / А. И. Гризодуб, О. А. Евтифеева, К. И. Проскурина // ФАРМАКОМ. - 2012. - № 6. - С. 7-30.

3. Державна Фармакопея України / Державне підприємство «Науково-експертний фармакопейний центр». - 1-е вид. - Харків : РІРЕГ, 2001. - с 169.

4. Смалюх О. Стандартизація багатокомпонентного рослинного лікарського засобу / О. Смалюх, С. Сур // Фармацевтичний часопис. № 2. - 2014. - С. 13.

5. Аналитическая химия в создании, стандартизации и контроле качества лекарственных средств: в 3-х томах / под редакцией член-кор. НАН Украины В. П. Георгиевского. - Харьков : Изд. «НТМТ», 2011. - С. 142.

6. Аналитическая химия в создании, стандартизации и контроле качества лекарственных средств: в 3-х томах / под редакцией член-кор. НАН Украины В. П. Георгиевского. - Харьков : изд. «НТМТ», 2011. - С. 948. 7. Морковь дикая, морковь обыкновенная / Б. Зузук, Р. Куцик, И. Гресько [и др.] // Провизор. - 2005. № 10. - С. 37-41.

8. Спектрофотометричне визначення флавоноїдів у плодах моркви дикої / М. Б. Чубка, Л.В.Вронська, С. В. Сур [та ін.] // Медична хімія. - 2011. - Т 13, № 1. - C. 88-94.

9. Смалюх О. Стандартизація плодів моркви дикої за складом і вмістом флавоноїдів / О. Смалюх, С. В. Сур // Актуальні питання фармацевтичної і медичної науки та практики. № 1. - 2013. - С. 88.

10. Смалюх О. Стандартизація цмину піскового квітів за складом і вмістом флавоноїдів / О. Смалюх, М. Нестер, С. В. Сур //Актуальні питання фармацевтичної і медичної науки та практики. - № 3. - 2013. - С. 95.

ISSN 2312-0967. Фармацевтичний часопис. 2015. № 1 
11. Чубка М. Б. Дослідження флавоноїдного складу насіння моркви дикої / М. Б. Чубка, Л. В. Вронська // Науково-технічний прогрес і оптимізація технологічних процесів створення лікарських препаратів: матер. 3-ї науково-практичної конференції „Науково-технічний прогрес і оптимізація технологічних процесів створення лікарських препаратів» (1-2 жовтня 2009 р., м. Тернопіль) / Ред. кол. : Л. Я. Ковальчук та ін. - Тернопіль : ТДМУ, 2009. - С. 34.

12. Державна Фармакопея України / Державне підприємство „Науково-експертний фармакопейний центр». - 1-е вид. - Доповнення 4. - Харків : РІРЕГ, 2011. - 329 с. 13. Державна Фармакопея України / Державне підприємство „Науково-експертний фармакопейний центр». 1-е вид. - Доповнення 2. - Харків : РІРЕГ, 2008. - 85 с. 14. Чубка М. Б. Валідація методики кількісного визначення сум флавоноїдів у плоду моркви дикої / М. Б. Чубка // Управління, економіка та забезпечення якості в фармації. - 2013. - № 1(27). - С. 18-21.

15. WHO monographs on selected medicinal plants, Volume 2, Flos Calendulae - Geneva: World Health Organization, 1999

\section{РАЗРАБОТКА СПЕКТРОФОТОМЕТРИЧЕСКОЙ МЕТОДИКИ ОПРЕДЕЛЕНИЯ ФЛАВОНОИДОВ В КОМПЛЕКСНОМ ЛЕКАРСТВЕННОМ СРЕДСТВЕ НА ОСНОВЕ ЭКСТРАКТОВ БЕССМЕРТНИКА ПЕСЧАНОГО, КАЛЕНДУЛЫ, МОРКОВИ ДИКОЙ И КУРКУМЫ ДЛИННОЙ}

\section{О. Г. Смалюх}

\section{ПАТ «Галичфарм»}

Резюме: разработан спектрофотометрический метод количественного определения суммы флавоноидов в лекарственном средстве на основе экстрактов бессмертника песчаного, календулы, моркови дикой и куркумы длинной в пересчете на изосалипурпузид. Проведена валидация разработанной методики по таким характеристикам, как линейность, правильность, прецизионность и робасность.

Ключевые слова: спектрофотометрия, флавоноиды, комплексное растительное лекарственное средство.

\section{DEVELOPMENT OF SPECTROPHOTOMETRIC TECHNIQUE FOR FLAVONOIDS ASSAY IN COMPLEX DRUG BASED ON EXTRACTS OF EVERLASTING, CALENDULA, WILD CARROT AND CURCUMA}

\section{O. G. Smalyuh}

\section{$P J S C$ «Galichfarm»}

Summary: the spectrophotometric technique for the quantitative determination of flavonoids recalculated as on izosalipurpuzid in complex drug based on extracts of Everlasting sand, Calendula, Wild Carrot and Curcuma longae was developed. The validation of developed technique was carried out on such characteristics as linearity, accuracy, precision and robustness.

Key word: spectrophotometry, flavonoids, complex herbal drug. 